\title{
Da sociedade de massa à sociedade civil: A concepção da subjetividade em Gramsci*
}

\author{
Giovanni Semeraro**
}

\begin{abstract}
RESUMO: Um dos maiores desafios políticos e pedagógicos que batem à porta do século XXI, particularmente para o Brasil, é superar a condição de massa e fortalecer uma sociedade civil criativa que nasce das aspirações populares e busca autodeterminação, cidadania e participação ativa na gestão democrática do poder. A concepção original de sociedade civil delineada por Gramsci é uma fonte de inspiração fundamental para enfrentar os impasses atuais e construir uma sociedade livre e democrática.
\end{abstract}

Palavras-chave: Sociedade civil, sujeito social, democracia, cidadania, autogoverno

\section{A nova política do protagonismo das massas}

Gramsci teve uma existência relativamente curta (1891-1937), mas viveu intensamente eventos históricos extraordinários que marcaram os rumos do nosso século: a Primeira Guerra Mundial, a Revolução Russa, os levantes operários na Europa, a formação de grandes partidos políticos, a consolidação de regimes totalitários, a depressão econômica de 1929, a afirmação dos Estados Unidos como potência hegemônica mundial.

\footnotetext{
* Texto apresentado para o Congresso Internacional: "Antonio Gramsci: Da un secolo all'altro", organizado pela Internacional Gramsci Society, no Istituto Italiano per gli Studi Filosófici, Napoli, 16-18 de outubro de 1997.

** Professor de Filosofia da Educação da Universidade Federal Fluminense (UFF).
} 
Nesse período, aparecem já claras as características dominantes das décadas seguintes: a emergência crescente das massas e as dimensões globais e instantâneas que vieram adquirindo as complexas relações humanas. Hoje, favorecidos por um olhar retrospectivo sobre o século que se fecha, percebemos melhor que o mesmo fenômeno tem percorrido todos os continentes estreitando-os em um destino comum. Não apenas as guerras "totais" - as mais catastróficas da história da humanidade -, mas "filhas" dessas, as revoluções políticas e culturais fizeram do 'novecento' um século "breve" e convulsivo marcado por tensões "extremas" que mesclaram inauditos massacres humanos com prodigiosas conquistas científicas e tecnológicas. ${ }^{1}$

$\mathrm{Na}$ "aldeia global" em que se transformou o nosso mundo, nada acontece que não envolva amplas camadas da população. As massas tornaramse a chave de nosso tempo: quer se procure a sua legitimação instrumentalizando-as passivamente, quer elas, de baixo, manifestem ativamente as suas reivindicações nas mais diversas expressões. Assim, enquanto, de um lado, se multiplicam e se sofisticam os instrumentos de manipulação, de outro, a criatividade popular renasce obstinadamente, manifestando cada vez mais a sua vontade de escrever a história com as próprias mãos.

Gramsci esteve particularmente atento a essas transformações, envolvido em uma época em que a classe dominante havia perdido o consenso e "as grandes massas haviam se afastado da ideologia tradicional, não acreditando mais no que antes acreditavam. A crise consiste exatamente no fato de que o velho morre e o novo não consegue nascer".

Gramsci não era o primeiro a colocar-se a questão política da emergência das massas no cenário histórico contemporâneo. Hegel já havia observado que uma das maiores contradições dos tempos modernos derivava do crescimento vertiginoso da riqueza que não produzia a prosperidade, mas a pobreza e a "plebe". Em suas reflexões, estava também convencido de que a "moralidade" individual, a beneficência particular ou a assistência pública não iriam superar o mecanismo de multiplicação do surgimento da "plebe", 3 uma vez que se tratava de uma conseqüência estrutural do moderno sistema produtivo. A solução, para ele, deveria ser encontrada na constituição de um "Estado ético", omniabrangente, capaz de ultrapassar os conflitos da sociedade civil e garantir o funcionamento do todo.

Ao fenômeno das massas, Nietzsche - enquanto lança uma crítica radical à decadência da civilização ocidental e à sua moral servil - dedica só o desprezo e o chicote. A nova nobreza do "Super-homem", afirmava, deveria aprender a odiar a "plebe" e a combater a praga dos movimentos so- 
cialistas que procuravam reeditar em formas seculares as ilusões igualitárias pregadas pelo Cristianismo para as massas dos fracos e desorientados. ${ }^{4}$

No tempo de Gramsci não faltava quem, como Ortega y Gasset, vendo na "rebelião das massas" uma ameaça à ordem social e às tradições ocidentais, estimulasse as elites intelectuais a assumir a "educação" das massas e a dirigi-las politicamente. G. Sorel, por outro lado, pregava a "cisão" dos trabalhadores da sociedade burguesa e, lançando um apelo ao mito unificador da "greve geral", incentivava a ação direta das massas, sem recorrer às "ambíguas" mediações políticas.

Assim, quando por toda parte se pensava que a saída para a grave crise histórica iria surgir da afirmação de um Estado forte, dos métodos da "guerra de movimento" ou da integração das massas nas velhas formas políticas, Gramsci, rejeitando as soluções do fascismo e criticando as tendências à centralização do poder, ${ }^{5}$ sustentava que uma nova civilização só poderia vir à luz pelo ingresso na história das massas livre e democraticamente organizadas. Diferentemente da maioria de seus contemporâneos, o pensador italiano estava convencido de que somente por meio do desenvolvimento de uma consciência histórica da realidade e de uma ação política voltada a elevar a condição "intelectual e moral" das massas se poderia chegar a uma sociedade realmente "civil", capaz de humanizar-se plenamente e de autogovernar-se. A solução à "crise de autoridade", ou seja, de "hegemonia" ou de "Estado no seu conjunto", deveria ser encontrada no reconhecimento da passagem, já em ato nas práticas das massas, "da passividade política para uma certa atividade [na qual] apresentam reivindicações que no seu conjunto desorgânico constituem uma revolução". ${ }^{6}$

A trágica experiência da Primeira Guerra Mundial (1914-1918) havia, de fato, provocado uma ruptura irreparável entre massas populares e ideologias dominantes, minando toda a credibilidade nos métodos tradicionais da política baseada, sobretudo, na força e na prepotência. Ora, não se podia mais pensar em administrar o poder apoiado unicamente sobre os sistemas coercitivos. O protagonismo e as aspirações à democracia, crescentemente demonstrados pelos movimentos que despontavam das iniciativas populares, favoreciam a expansão da sociedade civil e revolucionavam totalmente a concepção de Estado. ${ }^{7}$

O surgimento das complexas e diversificadas manifestações de democracia popular tornava-se, portanto, os novos espaços dentro dos quais era necessário repensar a política e elaborar os novos termos da hegemonia. Por isso, se fazia necessário alargar a concepção de Esta- 
do e de sociedade. Por um lado, de fato, não se podia mais pensar a sociedade civil como sendo uma realidade privada, de caráter exclusivamente econômico, agindo à parte da estrutura pública do Estado. Por outro, galvanizar os sentimentos das massas para conduzi-las mecanicamente, como um exército disciplinado, em direção a políticas massificadoras revelava-se um jogo anacrônico, além de perigoso.

Os tempos apresentavam sinais claros de que amplos setores da sociedade estavam já em condição de administrar a sua liberdade e de chegar a uma sociedade "auto-regulada". Gramsci percebia que os destinos da história e da política seriam decididos, cada vez mais, pela participação ativa das massas e pela criatividade dos diversos grupos organizados na sociedade civil. Assim, entende-se porque, juntamente com o desenvolvimento de uma concepção crítica e histórica da realidade, ele insistisse tanto nos elementos que favorecem a formação de uma personalidade própria dos trabalhadores, na liberdade e na capacidade de iniciativa, na função da cultura e no processo de subjetivação das camadas subalternas.

O amadurecimento desses elementos iria levar as classes trabaIhadoras a colocar-se como alternativa às teorias economicistas que induziam ao fatalismo e recorriam ao "transformismo" e à "revolução passiva", métodos aperfeiçoados pela "economia programática" americana que produzia o homem-máquina e o "gorila amestrado". Com tais sistemas não se chegava a "uma nova sociedade política e a um novo tipo de sociedade civil". ${ }^{8}$ As relações sociais entre as classes permaneciam inalteradas e a formação do homem-massa, despolitizado e atomizado, impedia o avanço efetivo dos setores populares. Gramsci, ao contrário, percebia, na formação "maciça" das modernas democracias e nas irrefreáveis associações da vida civil, ${ }^{9}$ um claro convite a socializar a política e a democratizar o poder, subordinando a doutrina da políticapotência à concepção da política-hegemonia. ${ }^{10}$

\section{Além do economicismo e do estatismo}

Consciente das transformações de seu tempo, Gramsci, quando trata das relações que intercorrem entre sociedade política e sociedade civil, procura evitar equívocos, seja de caráter economicista e liberal, seja de caráter organicista e totalitário. Os primeiros, identificando o Estado com o governo, separam o Estado da sociedade civil, considerando-a um setor au- 
tônomo, regulado por normas "naturais" de liberdade econômica: "Naturalmente, os liberais ['economicistas'] que consideram o Estado veilleur de nuit gostariam que a iniciativa histórica fosse deixada à sociedade civil e às diversas forças que aí despontam, com o 'Estado' guardião da 'lealdade do jogo' e de suas leis". ${ }^{11}$ As outras confusões derivam dos sistemas totalitários que visam identificar Estado e sociedade civil, unificando "ditatorialmente" os elementos da sociedade civil no Estado, na "desesperada busca de controlar toda a vida popular e nacional". ${ }^{12}$ Nesse caso, hegemonia e ditadura são unificados, o consenso é obtido com a força e todas as manifestações sociais acabam centralizadas e dominadas pelo Estado.

Essas duas posições, que no tempo de Gramsci eram representadas pelo liberalismo de Croce e pelo fascismo de Gentile, para além da aparente alternativa, mantinham laços comuns e se completavam reciprocamente. De fato, a identificação de Estado e governo das teorias liberais remetia a uma concepção de Estado como estrutura puramente jurídicocoercitiva, de gendarme, que não havia ainda superado a mera fase corporativa, que não havia se desenvolvido em sintonia com a maturação das forças sociopolíticas emergentes na história. Assim, essa incapacidade de renovar-se e de entender a realidade histórica concreta, disfarçada de liberdade e de neutralidade, abria o caminho para a fragmentação social e para o vazio político. A separação entre sociedade política e sociedade civil, de sinal de liberdade, acabava por transformar-se em condição propícia à formação de ideologias totalitárias prontas a intervir, principalmente nos momentos de crise e de desorientação geral.

Para evitar os perigos do "economicismo" e do "estatismo", Gramsci defende uma relação dialética de "identidade-distinção entre sociedade civil e sociedade política", ${ }^{13}$ duas esferas distintas e relativamente autônomas, mas inseparáveis na prática. De fato, a primeira - composta de organismos privados e voluntários - indica a "direção", enquanto a segunda estruturada sobre aparelhos públicos - caracteriza-se mais pelo exercício do "domínio". O Estado moderno não pode mais ser entendido como um sistema burocrático-coercitivo. As suas dimensões não podem se limitar aos instrumentos exteriores de governo, mas abarcam também a multiplicidade dos organismos da sociedade civil onde se manifesta a livre iniciativa dos cidadãos, seus interesses, suas organizações, sua cultura e seus valores, onde, praticamente, se estabelecem as bases do consenso e da hegemonia.

Os sistemas modernos de políticas democráticas se medem justamente pela capacidade de desenvolver uma ampla e dinâmica sociedade civil que permita expressar plenamente as aspirações e a participa- 
ção dos diferentes setores da vida coletiva. O que interessa a Gramsci, portanto, não é tanto a consistência do aparelho de Estado ou o vigor econômico de grupos privados, mas a criatividade e a articulação entre as diversas associações da sociedade civil, com os indivíduos aprendendo a política do autogoverno e a gestação de valores democráticos.

Nesse sentido, o Estado, os partidos e as diversas instituições existentes são entendidos como superáveis pela sociedade "regulada", o lugar onde as massas podem encontrar as condições para se tornarem sujeitos livres e socializados. Por isso, a verdadeira função de um Estado democrático deve ser "ética", "educativa", de "impulso histórico", de "elevação intelectual e moral das massas". ${ }^{14}$ O Estado se torna ético porque promove o crescimento da sociedade civil sem anular os espaços de liberdade dessa, de modo que a sociedade civil, à medida em que amadurece na responsabilidade e na socialização do poder, acaba anulando as intervenções externas e coercitivas do Estado e se transforma em "Estado sem Estado". Trata-se, na verdade, de uma "pura utopia", como o próprio Gramsci reconhece, mas "fundamentada sobre o pressuposto de que todos os homens são realmente iguais e portanto igualmente racionais e morais, quer dizer, passíveis de aceitar a lei espontaneamente, livremente e não por coerção, como imposta por uma outra classe, como coisa exterior à consciência". ${ }^{15}$

A novidade da noção de sociedade civil esboçada por Gramsci consiste no fato de que não foi pensada em função do Estado, em direção ao qual tudo deve ser orientado, como queria Hegel. Nem se reduz ao mundo exclusivo das relações econômicas burguesas, como queriam algumas interpretações das teorias de Marx. Para Gramsci, a sociedade civil é, antes de tudo, o extenso e complexo espaço público não estatal onde se estabelecem as iniciativas dos sujeitos modernos que com sua cultura, com seus valores ético-políticos e suas dinâmicas associativas chegam a formar as variáveis das identidades coletivas. É lugar, portanto, de grande importância política onde as classes subalternas são chamadas a desenvolver suas convicções e a lutar para um novo projeto hegemônico enraizado na gestão democrática e popular do poder.

Sem diminuir o peso das estruturas e da base econômica, Gramsci estabelece uma dialética entre sociedade civil e sociedade política e traça uma justa relação entre as condições objetivas da realidade e a vontade de organização de sujeitos ativos capazes de construir o "bloco histórico". Nessa relação, no entanto, o que deve emergir é sempre a promoção sociopolítica das massas, o desenvol- 
vimento dos valores da liberdade, da responsabilidade e da capacidade dirigente das classes trabalhadoras.

Gramsci não se afasta do marxismo, mas se diferencia das interpretações usuais pela insistência sobre a construção de sujeitos historicamente ativos e organizados que procuram conquistar a hegemonia com os métodos da democracia, subtraindo-a progressivamente à esfera de influência da burguesia. Por isso, mais do que evidenciar as aberrações do capitalismo, Gramsci confere uma ênfase particular à criatividade e à capacidade de iniciativas que devem aprender a desenvolver as classes subalternas. Estas, mais do que preocupar-se em resistir à opressão, são chamadas a buscar formas para sair da submissão e inventar os termos de uma nova sociedade.

Ao dessacar a importância da liberdade, das organizações e do envolvimento ativo das massas, Gramsci resgata, assim, toda a força educativa e mobilizadora do marxismo. Entende-se, assim, porque denuncia "o objetivismo materialista" que atribuindo um primado automático e absoluto às estruturas materiais, cria um fundamento pseudoteórico às concepções dogmáticas da revolução e justifica posições evolucionistas e mecanicistas: "O erro do materialismo histórico - afirmava Gramsci - reside no fato de considerar todo ato político, imediatamente, como determinado pela estrutura, ou seja, como reflexo de uma real e permanente... modificação da estrutura." ${ }^{16}$

A insistência sobre o primado da estrutura e a "objetividade" da realidade, para Gramsci, acabavam por abrir o caminho a visões metafísicas e a posições políticas estéreis. Nos anos que se seguiram à Primeira Guerra Mundial, de fato, o obstáculo maior que impediu o sucesso da revolução em um período de profunda crise socioeconômica do capitalismo veio exatamente da crença nas transformações automáticas das estruturas e da insuficiência dos elementos subjetivos. Gramsci não esquecerá jamais que o movimento socialista ocidental perdeu a ocasião de conquistar o poder por falta de iniciativa política. A incapacidade de organização e de determinação levou os socialistas a aceitarem passivamente a realidade histórica imposta pela iniciativa capitalista e a assistirem como espectadores impotentes aos eventos que se precipitavam. ${ }^{17}$

Desde os escritos juvenis, Gramsci havia denunciado a "esterilização" do pensamento de Marx operada pelos socialistas positivistas. Ao combater as posições "deterministas" e "transformistas", alertava contra o perigo de transformar as idéias revolucionárias de 
Marx em inércia do proletariado e de reduzir seu pensamento a esquema exterior, a lei natural que deve realizar-se fatalmente, "independentemente da vontade dos homens, das suas atividades associativas, das forças sociais que essas atividades desenvolvem, tornando-se, assim, determinantes para o progresso, motivo necessário de novas forças de produção". ${ }^{18}$ Contrariamente ao que se pensava, a concepção objetivo-mecanicista havia suscitado uma mentalidade de submissão e de fatalismo, uma ideologia de "resistência passiva" à hegemonia da classe dominante. Na realidade, quando as classes subalternas pensam em seguir as "leis da história", se submetem, de fato, à história feita pelos outros.

Gramsci não cansa de repetir que as concepções que sustentam a iniciativa e o desenvolvimento da subjetividade são próprias de um grupo social que se propõe a ser sujeito e protagonista da história. A subjetividade, de fato, é a típica maneira de ser das classes dirigentes, de quem exercita uma relação ativa com a realidade. Não se podia, portanto, pensar na emancipação dos trabalhadores enquanto se mantinha a submissão às regras e aos princípios da classe dominante. Para desenvolver no operário a "psicologia do produtor" e colocar a nova classe fundamental em condição de dirigir o processo histórico, era necessário desenvolver posições antitéticas à ordem existente. Mas, a ruptura, a "cisão", não era suficiente. Havia, principalmente, necessidade de elaborar e de concretizar um projeto de sociedade superior ao da classe dominante.

Deve ser entendida nesse sentido a insistência de Gramsci sobre a centralidade do conceito de história como processo, sobre a valorização da responsabilidade dos sujeitos e sobre a importância decisiva atribuída às organizações das classes subalternas. Na dinâmica da sociedade, de fato, interagem "forças materiais" e movimentos ético-políticos que formam um inseparável "bloco histórico". Entre "estrutura" e "superestrutura" deve existir, portanto, uma relação de reciprocidade na qual é possível combinar um amplo projeto político com planos econômicos criativos e participativos.

A própria estrutura, "conjunto de relações materiais de produção", ${ }^{19}$ é, para Grasmci, uma "realidade em movimento", é "história cristalizada", "condensação objetivada da práxis" ${ }^{20}$ que não deve ser confundida com a mera atividade física ou metafísica. Assim, se as condições objetivas "determinam" a ação política e as atividades das pessoas, o fazem apenas in negativo, pelo fato de que definem o campo de ação, os horizontes em que os sujeitos são delimitados, sem 
que com isso venha a se impedir a sua liberdade de iniciativa, as suas liberdades efetivas e a sua verdadeira autonomia.

Então, o ponto central das reflexões de Gramsci se prende à formação de novos sujeitos sociais que visam à construção de um projeto de sociedade aberto à participação de todos os trabalhadores. Nesse sentido, a consciência e a subjetividade representam uma dimensão fundamental na ação política, uma vez que se é verdade que não é a consciência que determina o ser social, é também verdade que só por meio da consciência o homem pode apropriar-se das funções da sociedade e ter condição de realizá-las lutando contra as pressões externas que condicionam seu comportamento e neutralizam suas aspirações.

\section{As raízes da democracia na sociedade civil}

Já foi observado que o desenvolvimento dos elementos da subjetividade é a contribuição mais significativa de Gramsci ao marxismo contemporâneo, no âmbito do qual opera uma verdadeira refundação da filosofia. ${ }^{21} \mathrm{Na}$ base dessa afirmação estão a concepção histórica e imanente de seu pensamento, a importância que Gramsci atribui aos elementos da liberdade e da vontade, a insistência sobre a "reforma intelectual e moral", o papel da escola e da cultura, a formação da consciência e a participação ativa das classes subalternas nas novas organizações sociais, a função positiva das ideologias, a construção de uma nova concepção de mundo superior à da classe dominante burguesa e, acima de tudo, a procura dos fundamentos ético-políticos e do consenso na construção da hegemonia.

Gramsci funda a noção de subjetividade na "filosofia da práxis", uma concepção na qual os homens são sujeitos reais da história e não instrumentos passivos de determinações materiais ou espirituais. A "filosofia da práxis", de fato, se enraíza, ao mesmo tempo, no imanentismo e na "concepção subjetiva da realidade, pelo fato de que a domina, explicando-a como fato histórico, como 'subjetividade histórica de um grupo social', como fato real que se apresenta como fenômeno de 'especulação' filosófica; mas, na realidade, é simplesmente um ato prático, a forma de um conteúdo social concreto e o modo de conduzir o conjunto da sociedade a conseguir uma unidade moral". ${ }^{22} \mathrm{O}$ homem, para Gramsci, é impensável fora da história das relações sociais e das transformações operadas pelo 
trabalho organizado socialmente. A originalidade da filosofia da práxis consiste, exatamente, no fato de ser uma teoria que leva adiante as dimensões da subjetividade da filosofia moderna sem fazer concessões às tendências idealistas ou mecanicistas, uma vez que se ocupa das transformações da realidade por meio de uma consciência nunca separada dos condicionamentos sociais e dos conflitos de classe.

A dimensão subjetiva e o momento ético-político, para Gramsci, não são o resultado de um efeito mecânico proveniente de estruturas objetivas, nem se identificam com alguma idéia predeterminada que dirige a história misteriosamente, mas são a expressão mais elevada do projeto hegemônico de sociedade que as classes subalternas são capazes de construir quando se constituem como sujeitos conscientes e ativos. Nesse difícil e complexo processo de subjetivação, as novas forças sociais, antes agrupadas em sistemas econômico-corporativos, assumem progressivamente atitudes em contraposição à ideologia dominante até amadurecer uma visão independente e superior de mundo, para a qual convergem os diferentes grupos que lutam pelos mesmos horizontes sociais e políticos.

Como se sabe, Gramsci chama esse processo de "catarse", ou seja, "a passagem do momento meramente econômico (ou egoístico-passional) ao momento ético-político, quer dizer, a elaboração superior da estrutura em superestrutura na consciência dos homens (...). A estrutura, de força exterior que esmaga o homem, o anula, o torna passivo, transforma-se em possibilidade de liberdade, em instrumento para criar uma nova forma ético-política, em origem de novas iniciativas". ${ }^{23}$ A "catarse", como processo de transformação efetivo da realidade individual e social, não apenas impede que a filosofia se torne dogmática e especulativa, mas é o modo pelo qual, nessa passagem da estrutura à superestrutura, da necessidade à liberdade, o indivíduo se transforma em ser socialmente relacionado, capaz de construir o sentido unitário da sociedade e de formar o "bloco histórico", que permite integrar dialeticamente as forças da esfera econômica com as expressões culturais e a participação política das massas excluídas.

Em seu conjunto, o pensamento de Gramsci está voltado para municiar as organizações das classes subalternas que lutam para conquistar a sua liberdade e a sua hegemonia. Nesse sentido, vai além da noção de "sociedade civil" que, na história moderna, passou a significar mais exatamente o espaço próprio da burguesia, a constituição de relações que, além da estrita esfera do Estado, vieram se formando em torno do mercado e da livre iniciativa, assim como das 
normas que se criaram para regular a propriedade privada na complexa dinâmica das novas sociedades.

Embora as origens do conceito de sociedade civil estejam relacionadas com a tradição política burguesa e liberal, Gramsci elabora um novo significado que o diferencia da tradição jusnaturalista e o conduz além dos horizontes desenhados por Hegel, Croce e pelo próprio Marx. Âmbito particular da subjetividade e de suas múltiplas expressões, a sociedade civil não é apenas o território exclusivo da burguesia, reservado para as suas iniciativas econômicas e a estruturação de sua hegemonia no mundo moderno. Gramsci percebe que esse espaço pode, também, transformar-se em uma arena privilegiada onde as classes subalternas organizam as suas associações, articulam as suas alianças, confrontam os seus projetos ético-políticos e disputam o predomínio hegemônico. A modernidade, de fato, não só deu origem ao capitalismo e à autonomia pessoal, como também abriu a estrada à emancipação das massas e lançou as premissas da democracia social. $E$ se é verdade que no Ocidente as estruturas da sociedade civil se desenvolveram simultaneamente às estruturas do mercado capitalista e a formas particulares de industrialismo, seria um "erro deduzir disso a existência de uma única lógica social que veja sociedade civil, capitalismo e industrialismo indissoluvelmente associados". ${ }^{24}$

O socialismo, como democracia radical, pode, atuando no mesmo terreno da sociedade civil que deu origem a formas de vida burguesa, superar a lógica do capital e criar uma nova lógica industrial com base nos princípios de participação ativa das classes trabalhadoras e da socialização do poder. Nesse sentido, entende-se por que Gramsci, utilizando uma diferente tradição de pensamento, alarga e supera com originalidade o conceito de sociedade civil e a própria concepção de mundo das teorias liberais.

$\mathrm{Na}$ realidade, pode-se dizer que com o conceito de sociedade civil acontece o que $\mathrm{N}$. Bobbio argutamente observa em relação à transformação da categoria "Estado ético", utilizada por Gramsci, que "se serve de uma expressão de seus adversários, de uma expressão não-marxista para designar um conceito típico da filosofia política marxista, e o faz invertendo literalmente o sentido, ou seja, interpretando-o não como forma sublimada de Estado, mas como negação e fim do Estado". ${ }^{25}$

Quando se observa o processo de assimilação e de superação do conceito de "sociedade civil" nos textos de Gramsci, percebe-se o mesmo mecanismo de transformação. Em parte, o conceito conserva os valores típicos da modernidade: a liberdade, a laicidade, o espírito de ini- 
ciativa, a consciência crítica, a subjetividade, a dinâmica e a historicidade das relações sociais. Mas Gramsci não se limita a estas características. Contrariamente à concepção prevalecente no mundo liberal-burguês que parte do indivíduo como realidade completa em si mesma e dos próprios interesses como finalidade última de todas as coisas -, Gramsci parte das necessidades concretas das classes subalternas, de experiências como as dos "Conselhos de fábrica" de Turim, onde os indivíduos chegam a se organizar socialmente e a conquistar espaços hegemônicos para o seu projeto de sociedade. Naquela experiência, marcante para o resto de sua vida, ficou provado que um movimento de fábrica tende a transformar em "subjetivo" o que é posto "objetivamente", que de um sistema de fábrica pode surgir uma "vontade coletiva" capaz de operar uma relativização do modo capitalista de produção e introduzir uma "ruptura" radical entre capitalismo e industrialismo: "o nexo pode dissolver-se; a exigência técnica pode ser pensada concretamente separada dos interesses da classe dominante, não só, mas unida aos interesses da classe ainda subalterna. Que uma tal ruptura e nova síntese seja historicamente madura está demonstrado peremptoriamente pelo próprio fato de que um tal processo é apropriado pela classe subalterna, que por isso mesmo não é mais subalterna, ou seja, demonstra querer sair de sua condição subordinada". ${ }^{26}$

$\mathrm{Na}$ visão do liberalismo, a sociedade civil é o espaço do indivíduo separado da esfera do Estado, estrutura exterior e opressora mas inevitavelmente necessária para moderar os "excessos" dos interesses privados. Aqui, o ponto de partida e de chegada é sempre a liberdade e o benefício do indivíduo. Em Gramsci, ao contrário, a sociedade civil é o terreno onde indivíduos "privados" de sua dignidade e pulverizados em suas vidas podem encontrar condições para construir uma subjetividade social, podem chegar a ser sujeitos quando, livre e criativamente organizados, se propõem a desenvolver, juntamente com as potencialidades individuais, suas dimensões públicas e coletivas. O percurso, nesse sentido, vai do ser privado ao ser social. O indivíduo, aqui, sem deixar de ser centro autônomo de decisões, consciência livre e ativa, nunca é entendido como ser isolado e "mônada" auto-suficiente em si mesma, mas é sempre visto dentro de uma trama social concreta, como um sujeito interativo com outros sujeitos igualmente livres, com os quais se defronta e constrói consensualmente a vida em sociedade. Nesse sentido, a concepção de liberdade, para Gramsci, adquire uma conotação positiva, de expansão 
social, não de diminuição e de limitação: a liberdade individual não termina onde começa a dos outros, mas se desenvolve ainda mais quando se encontra com a dos outros.

Ao defender a condição de sujeitos livres e ativos também para as massas populares, Gramsci reinterpreta o conceito de homem como ser social e como cidadão de uma sociedade tão "civil" que chega ao ponto de não precisar do Estado como uma instância exterior, uma vez que a liberdade toma o lugar da necessidade e o autogoverno, o lugar do comando.

O Estado, em Gramsci, torna-se supérfluo não porque o privado não admite interferências em sua esfera, mas porque nas massas se desenvolve a responsabilidade pelo público e pelo coletivo. Ao "absorver" a sociedade política, a nova sociedade civil - que surge das organizações populares e valoriza a sua criatividade - torna-se um organismo público, cria um novo Estado capaz de orientar a economia e as potencialidades sociais na direção do interesse geral. Gramsci não postula uma sociedade sem Estado, ${ }^{27}$ mas uma nova sociedade que cria um novo tipo de Estado. E, da mesma forma que vê uma relação dialética - "difícil de entender para mentalidades esquemáticas e abstratas" - entre o desenvolvimento da subjetividade crítica e a formação do homem-coletivo, assim também afirma que "é difícil compreender como pela destruição da máquina estatal se possa chegar a criar uma outra mais forte e complexa" ${ }^{28} \mathrm{Na}$ realidade - e aqui a posição de Gramsci chega a ser ainda mais original -, o primado do público não significa estabelecer um aparelho estatal que regule coercitivamente a atividade dos indivíduos e dos grupos. O interesse social e as organizações públicas, que devem ser criadas continuamente, não sufocam as liberdades individuais. Para Gramsci, de fato, não existe "um todo antes das partes" como na filosofia aristotélica reativada por Hegel. Nem existe uma idéia de totalidade cujo fim - superior à soma das partes - absorve a sociedade civil no Estado. Ao afastar-se da concepção liberal, Gramsci não abraça as teorias totalitárias do Estado nem adere a visões comunitaristas ou populistas. ${ }^{29}$ A totalidade e a organicidade que Gramsci defende são as que surgem (e precisam sempre ser recriadas!) das relações livres e conscientes de sujeitos sociais que, nas diferenças e nos conflitos, chegam a construir um consenso ativo e uma hegemonia cuja estabilidade depende de constante avaliação e de aprovação da sociedade.

Contrariamente ao que se pensa, portanto, Gramsci não é o teórico do Estado, mas o intelectual-militante das classes trabalhadoras em movimento na sociedade civil e em busca de uma cidadania construída 
na participação e na responsabilidade. Gramsci não trabalha para erguer um Estado que distribua benefícios e proteção, mas para elevar intelectual e moralmente camadas cada vez mais amplas da população, ou seja, "para dar personalidade ao amorfo elemento de massa". ${ }^{30}$ A sua verdadeira preocupação é chegar a realizar nos indivíduos o salto revolucionário da condição de excluídos e de assalariados à de cidadãos que tomam parte não apenas do processo de produção mas também da direção política e cultural: "O valor mais importante não é que o camponês se torne agrônomo ou que o pedreiro se torne mestre, mas que o cidadão chegue a ser governante."

Contemporâneos, praticamente, de Gramsci, os teóricos da Escola de Frankfurt também dedicaram grande parte de seus esforços a análises brilhantes do processo de massificação para o qual havia desaguado o contraditório projeto do lluminismo. Em suas críticas, juntamente com os avanços da liberdade e da ciência que visavam reduzir as desigualdades entre os homens, destacavam o surgimento de sofisticados mecanismos de controle que haviam acabado por concentrar-se nas mãos de um poder que degenerara na ditadura da razão e na dissolução da sociedade. Diante das barbáries da Segunda Guerra Mundial e da massificante expansão da indústria cultural, tiravam suas conclusões sobre a falência da "razão instrumental" que, de promessa de libertação e de felicidade universal, havia se convertido em instrumento de dominação e de morte. ${ }^{31}$

No pós-guerra, também Hannah Arendt sondava, como poucos, "as origens do totalitarismo" e suas nefastas repercussões sobre a história ocidental. Para superar a triste experiência da massificação de indivíduos atomizados e desorientados, presa fácil de políticos alucinados, $\mathrm{H}$. Arendt defende a separação da esfera privada da pública, valoriza os recursos do sujeito e resgata o espaço público como "transparência" dos indivíduos e esplendor da política, à semelhança do modelo político do classicismo greco-romano. ${ }^{32}$

Mesmo diante de reflexões tão fundamentadas, Gramsci não chega a ser ofuscado no seu modo peculiar de abordar a questão das massas. Para o pensador sardo, de fato, as virtudes republicanas dos antigos, porquanto sirvam de inspiração, não são suficientes para resolver os problemas postos pela modernidade. Nem o resgate da personalidade individual conseguirá desenvolver todas as dimensões da "condição humana" na complexa trama das relações sociais contemporâneas. Ainda que seja necessário estabelecer canais de "comunicação" e fundar um espaço público, a transformação das condições de vida de todos os 
possíveis interlocutores não está totalmente assegurada por esse processo. A vida em sociedade, para Gramsci, não se limita ao nobre exercício do logos ou à demonstração de "façanhas" pessoais em busca da imortalidade, mas comporta principalmente uma práxis política consciente e coletiva que visa transformar a realidade, combate os privilégios e promove o protagonismo das massas espoliadas e excluídas. Sem ficar prisioneiro do "pessimismo" e da impotência diante dos sistemas "onipotentes" de dominação, Gramsci confia no "otimismo da vontade" e na capacidade de iniciativa e de organização que surgem das classes dos trabalhadores na dinâmica da história. O exercício da crítica, ainda que necessário, não é suficiente para formar o novo ser social capaz de vencer as manipulações do poder e chegar ao autogoverno. Restam fundamentais, no complexo processo de globalização em curso, a determinação e a intervenção ativa das massas preparadas e articuladas.

Diante das imensas possibilidades associativas que vê despontar na sociedade contemporânea, Gramsci lança um olhar otimista sobre as inimagináveis transformações que podem se realizar em uma história que nunca se abriu tanto às dimensões globais da socialização: "Porque 0 indivíduo pode associar-se com todos os que querem a mesma mudança e, se essa mudança é racional, o indivíduo pode multiplicar-se por um número incalculável de vezes e obter uma mudança muito mais radical da que parecia possível à primeira vista. Sociedades às quais o indivíduo pode participar: são muito numerosas, mais do que se pode imaginar. É por meio dessas 'sociedades' que o indivíduo faz parte do gênero humano". ${ }^{33}$

Os horizontes políticos traçados por Gramsci abrem-se, assim, às dimensões universais, não apenas porque entende a história da humanidade como um todo intercomunicante, mas principalmente porque reconduz à própria sociedade, às forças vivas nela operantes, a responsabilidade direta da política e a sua capacidade de definir-se livremente.

As novas perspectivas que Gramsci confere à dinâmica da sociedade civil revolucionam, portanto, não apenas a concepção tradicional de política e de Estado, mas destituem de fundamento qualquer visão centralizadora de poder e dissolvem toda pretensão de construir a hegemonia pelo alto, valendo-se da força, do peso econômico ou das manipulações demagógicas.

Ao apostar no potencial mobilizador da sociedade civil, Gramsci desloca o eixo principal da ação política do âmbito das instituições burocrático-administrativas para o terreno criativo das diversas organiza- 
ções sociais dos setores populares, e rompe o horizonte que se quer apresentar como "fim da história".

A 60 anos de sua morte, podemos concluir que Gramsci conserva, nos aspectos mais cruciais de seu pensamento, toda a atualidade e a força da inspiração, e nos ajuda, com a originalidade de suas perspectivas, a operar a passagem "de um século para o outro" com a tarefa, ainda a ser realizada, de democratizar os diferentes setores da sociedade e de enfrentar o desafio mais provocante apresentado à política moderna, que é o de abrir caminho à ação das massas, a personagem principal que há tempo pressiona as portas para entrar na história e, como sujeitos livres e autônomos, decidir os rumos do próprio destino.

\section{Notas}

1. HOBSBAWM, E. Era dos extremos. O breve século XX: 1914-1991, São Paulo, Companhia das Letras, 1994, pp. 51-62.

2. GRAMSCI, A. Quaderni del Carcere, 3,311 , a cura di V.GERRATANA, Torino, Einaudi, 1975. De agora em diante se usará a sigla Q.

3. HEGEL, G.W.F. Lineamenti della Filosofia del Diritto. Diritto naturale e scienza dello Stato in compedio, a cura di G. MARINI, Roma-Bari, Laterza, 1996, § 245: "Desse modo se mostra que, apesar do seu excesso de riqueza, a sociedade civil não é suficientemente rica, isto é, na sua riqueza, não possui a quantidade de bens para pagar o tributo ao excesso de miséria e à sua conseqüente plebe".

4. NIETZSCHE, F. Genealogia della morale. Scelta di frammenti postumi: 18861887, a cura di M. COLLI e M. MONTINARI, Milano, Mondadori, 1991, p. 15 e pp. 38-39.

5. Nos últimos anos antes da prisão, Gramsci entra em conflito direto não apenas com o fascismo na Itália, mas também com a centralização do poder e o processo de burocratização que começava a se implantar na URSS. Vejase, a propósito, a célebre Lettera al Comitato Centrale del PCS e a réplica à resposta de Togliatti, in: GRAMSCI, A., Lettere: 1908-1926, Torino, Einaudi, 1992, pp. 455-473. Ver, também, Q. 13, 1604: "A burocracia é a força rotineira e conservadora mais perigosa: quando consegue construir um corpo sólido, independente e separado da massa, o partido se torna anacrônico e, nos momentos de crise aguda, acaba esvaziado de seu conteúdo social e permanece como que suspenso no ar".

6. Q. 13, 1603. 
7. Q. 7,876 .

8. Q. 4, 460-461.

9. Q. $13,1567$.

10. VACCA, G., Gramsci e Togliatti, Roma, Ed. Riuniti, 1991, p. 13.

11. Q. 26, 2302-2303.

12. Q. 6, 763.

13. Q. 8, 1028.

14. Q. 10, 1302.

15. Q. 6, 764.

16. Q. 7, 872.

17. Veja-se, por exemplo: GRAMSCI, A., "Socialisti e comunisti", 12 marzo 1921, pp. 104-105, ou "La tattica del fallimento", 22 settembre 1921, pp. 347-348, in: Socialismo e fascismo. L'Ordine Nuovo: 1921-1922, Torino, Ed. Einaudi, 1966.

18. GRAMSCI, A., La città futura: 1917-1922, a cura di S. CAPRIOGLIO, Torino, Ed. Einaudi, 1982, pp. 554-555.

19. Q. 4, 444.

20. Q. 7, 854.

21. FERRARA, G., "Forme della rappresentanza e governo della società", in: TEGA, W. (a cura di), Gramsci e l'Occidente, Bologna, Cappelli Ed., 1990, p. 234. Ver, também, SALVADORI, M., Gramsci e il problema storico della democrazia, Torino, Ed. Einaudi, 1970.

22. Q. 10, 1226.

23. Q. 10, 1244.

24. TEXIER, J., "Il concetto gramsciano di 'società civile' e l'indipendenza personale”, in: AA.VV., Gramsci e il marxismo contemporaneo, op. cit., p. 31.

25. BOBBIO, N., Saggi su Gramsci, Milano, Feltrinelli, 1990, pp. 103-104.

26. Q. 9, 1138.

27. É bom lembrar que quando Gramsci fala da dissolução do Estado se refere à superação do Estado capitalista, origem das divisões e das guerras, não à eliminação das instituições necessárias à convivência social. De fato, para Gramsci, "A sociedade sem Estado é pura abstração" (L'Ordine Nuovo, op. cit., p. 377). A construção da "sociedade regulada" não significa inexistência de leis ou Estado, mas que as leis e o Estado devem ser o resultado de decisões livres e autônomas e não de imposições heteronômicas e autoritárias.

28. Q. 9, 1111. 
29. Desde seus escritos juvenis, Gramsci sempre defendeu que “... O Estado socialista ... não é a evolução do Estado capitalista ... mas continua e é um desenvolvimento sistemático das organizações profissionais e das entidades locais que o proletariado soube suscitar espontaneamente, por própria conta. A atividade que o proletariado realiza não pode absolutamente levar à aplicação dos poderes e do intervencionismo do Estado, mas deve levar à descentralização do Estado burguês, à expansão das autonomias locais e sindicai para além da lei reguladora" (GRAMSCI, A., "Dopo il Congresso", in: Scritti Giovanili (1914-1918), Torino, Ed. Einaudi, 1972, p. 315).

30. Q. 11, 1420-1430.

31. Ver, principalmente, HORKHEIMER, M., Eclipse da Razão, Rio de Janeiro, Editorial Labor do Brasil, 1976, pp. 139 ss. e ADORNO, T. W. \& HORKHEIMER, M., Dialética do Esclarecimento, Rio de Janeiro, J. Zahar Editor, 1985.

32. ARENDT, H., The Origins of Totalitarianism, New York, 1966, e The Human Condition, New York, Doubleday, 1959.

33. Q. $10,1346$.

\section{From mass society to civil society: The conception of subjectivity in Gramsci}

ABSTRACT: One of the greatest political and pedagogical challenges at the turn of the century, particularly in Brazil, is to go beyond the life from masses and strengthen a creative civil society which rises of diverse popular aspirations and searches for self-determination, citizenship and active participation in a democratic management of power. The original conception of civil society, delineated by Gramsci, is a source of fundamental inspiration for overcoming the present impasse and for constructing a free and democratic society.

\section{Bibliografia}

ADORNO, T.W e HORKHEIMER, M. dialética do esclarecimento. Rio de Janeiro: J. Zahar Editor, 1985.

ARENDR, H. The human condition. Nova York: Doubleday, 1959. . The origins of totalitarism. Nova York: Doubleday, 1966.

BOBBIO, N. Saggi su gramsci. Milão: Feltrinelli, 1990. 
FERRARA, G. "Forme della rapresentanza e governo della società". In: TEGA, W. (org.) Gramsci e l'Occidente. Bolonha: Cappeli, 1990.

GRAMSCI, A.. "Socialistie comunisti" (12 mar.1921). In: Socialismo e facismo.L'Ordine Nuovo: 1921-1922. Turim: Einaudi, 1966, pp. 104105.

. "La tattica del fallimento" (22 set. 1921). In: Socialismo e facismo.L'Ordine Nuovo: 1921-1922. Turim: Einaudi, 1966, pp. 347348.

Quaderni del carcere, 3,311 (a cura di V. Gerratana). Turim: Einaudi, 1975.

. "Dopo il Congresso". In: Scritti giovanili (1914-1918). Turim: Einaudi, 1972.

. La cittá futura: 1917-1922 (a cura di S. Caprioglio). Turim: Einaudi, 1982. . Lettere: 1908-1926. Turim: Einaudi, 1992.

HEGEL, G.W.F. Lineamenti della filosofia del diritto. Diritto naturale e scienza dello Stato in compendio (a cura di G. Marini). Roma-Bari: Laterza, 1996.

HOBSBAWM, E. A era dos extremos. O breve século xx: 1914-1991. São Paulo: Companhia das Letras, 1994.

HORKHEIMER, M. Eclipse da razão. Rio de Janeiro: Editorial Labor do Brasil, 1976.

NIETZSCHE, F. M. Genealogia della morale. Scelta di frammenti postumi: 1886-1887 (a cura di M. Colli M. e Montinari). Lilão: Mondadori, 1991.

SALVADORI, M. Gramsci e il problema storico della democrazia. Turim: Einaudi, 1970.

VACCA, G. Gramsci e Togliatti. Roma: Riuniti, 1991. 